\title{
MídiAs NA EdUCAÇ̃̃o: \\ Reflexões em torno da apropriação instrumental e leitura crítica das mídias ${ }^{1}$
}

\author{
MEDIA IN EDUCATION: \\ Reflections on instrumental appropriation and \\ critical reading of media
}

\section{ESTHER SILVA DA COSTA ${ }^{2}$ GISELLE MARTINS DOS SANTOS FERREIRA ${ }^{3}$}

Resumo: A necessidade de apropriação das mídias na educação emerge do cenário sociocultural contemporâneo que está delineado pela presença das mídias nas diversas esferas sociais. Entretanto, para garantir que os processos educacionais integrem qualitativamente as mídias, não basta utilizá-las instrumentalmente em sala de aula. Coloca-se como necessária a consolidação de um lugar na educação para as mídias onde haja a articulação das dimensões de "ferramenta pedagógica” e "objeto de estudo". À luz dessa afirmação o presente artigo aborda temas relacionados às apropriações das mídias na educação, refletindo sobre como os docentes e futuros docentes podem desenvolver ações verdadeiramente mídia-educativas, isto é, que não subutilizam as mídias nos processos educacionais.

Palavras-chave: mídia; educação; leitura crítica das mídias; formação docente.

Abstract: The need for the integration of media in educational situations emerges from the contemporary socio-cultural scenario outlined by the significant media presence in social spheres. However, to ensure quality in educational uses of media, it is not sufficient to use them instrumentally in the classroom. Indeed, it remains crucial that a legitimate space for media in education is consolidated, a space where a meaningful articulation is done between

\footnotetext{
${ }^{1}$ Trabalho apresentado no IV Seminário de Pesquisas em Mídia e Cotidiano da Universidade Federal Fluminense.

${ }^{2}$ Mestre em Educação e Cultura Contemporânea pela Universidade Estácio de Sá, na linha de pesquisa Tecnologias de Informação e Comunicação nos Processos Educacionais e Jornalista Especializada em MídiaEducação pela PUC-Rio.E-mail: esc.esther@oi.com.br

${ }^{3}$ Professora Adjunta do Curso de Pós-Graduação em Educação e Cultura Contemporânea da Universidade Estácio de Sá. É Mestre e Pós-Doutora em Educação pela Open University e possui várias especializações em teoria e métodos de pesquisa nas Ciências Sociais e Humanas. É Membro da Academia Britânica de Educação Superior desde 2001.E-mail: giselle.ferreira@sky.com
} 
the dimensions of "teaching tool" and "object of study". It involves thinking about how education can help students to become creative and critical users of these media. In light of this statement, this article discusses issues related to the appropriation of media in education, reflecting on how teachers and future teachers can develop truly media-educational actions, i.e. not underutilize the media in educational processes.

Keywords: media; education; critical reading of media; teacher training.

\section{Introdução}

O cenário da vida contemporânea caracteriza-se pela significativa presença das mídias nas diversas dimensões sociais. Por um lado, têm-se as tradicionais mídias analógicas e, por outro, as novas mídias digitais. No cotidiano familiar, por exemplo, é comum que as famílias iniciem conversas a partir dos temas emergentes das mídias, em especial a televisão. No campo profissional, as mídias estão potencializando os processos de comunicação e promovendo a integração global, enquanto que, no lazer, elas estão cada vez mais presentes e interativas, em especial com o fortalecimento e ampla disseminação das redes sociais. Essa presença das mídias alçou-as a um papel relevante no processo de construção do conhecimento, que passa a se realizar também através dessas redes e informações midiáticas.

As mídias estão se tornando mais sofisticadas e acessíveis, e ao mesmo tempo em que possibilitam realizar as principais mediações dos cidadãos, transformam-se nos grandes espaços de identificação e de projeção de todos nós (MORAN, 2007). O século XX viu as mídias se tornarem objetos de consumo de massa essenciais no cotidiano, e, no século XXI, a cultura midiática se intensifica de forma contínua com o crescimento global da Internet e suas potencialidades comunicacionais. Os serviços das mídias analógicas, entre eles os de informação e entretenimento, são centralmente produzidos e padronizados para serem difundidos a grandes públicos através de diferentes canais. As mídias digitais, no entanto, transformaram essas condições. Nelas, os serviços nem sempre derivam de uma fonte central, sendo frequentemente especializados, de modo a atender a diversos segmentos do público, e a distribuição de produtos de voz, vídeo e impressos ocorre em um canal eletrônico comum, no qual os formatos interativos bidirecionais permitem um maior domínio sobre os serviços (DIZARD, 2000). As mídias digitais, com suas redes interativas, estão crescendo 
exponencialmente e criando novas formas e canais de comunicação, moldando a vida e, simultaneamente, sendo moldadas por ela (CASTELLS, 1999).

Observamos, neste atual contexto sociocultural, a sobreposição dos conceitos de educação, informação, comunicação e entretenimento (LEITE, 2008). Inúmeras vezes esses conceitos passam pelas mídias, por meio das quais grande parte da sociedade se informa, se diverte e, simultaneamente, tem oportunidades de trabalho. Antes dessa imbricação de conceitos, o entretenimento estava ligado apenas ao lazer. Hoje, entretanto, torna-se uma ampla possibilidade de negócio, que penetra em quase todas as áreas de atividade humana. Por outro lado, o conceito de trabalho, no qual estavam enraizadas a imposição e a obrigação, hoje ganha outras dimensões, que podem associá-lo, em diversas situações, ao lazer, à viagem e ao esporte (LEITE, 2008).

Nos séculos XVII e XVIII, a informação era descrita como inteligência, ou seja, toda pessoa que possuísse informação era considerada inteligente; a educação como instrução, ou seja, pessoas que tivessem qualquer instrução, mesmo que elementar, eram consideradas educadas; e o entretenimento como recreação, passatempo, diversão; não havia sobreposição de conceitos. Eram três conceitos, ou áreas sociais distintas. Porém a industrialização deu um novo significado a cada termo dessa trindade (LEITE, 2008).

A cibercultura e a "sociedade da informação" também se consolidam a partir do entrelaçamento desses conceitos em suas novas acepções. A cibercultura consiste "(n)o conjunto de técnicas (materiais e intelectuais), de práticas, de atitudes, de modos de pensamento e de valores, que se desenvolvem juntamente com o crescimento do ciberespaço” (LÉVY, 1999, p. 17), esse “novo” espaço virtual onde ocorrem essas práticas e atitudes de comunicação e sociabilidade.

O ciberespaço rompe com o domínio da mídia de massa, fundamentada na transmissão, e permite uma comunicação mais aberta, personalizada, participativa e colaborativa (SILVA, 2010b). Dessa maneira, a cibercultura provém de um mundo virtual repleto de novos significados, que estão transformando, no mundo real, as linguagens, os espaços e o tempo. Um exemplo dessa transformação se traduz no princípio de liberação da palavra (LEMOS; LÉVY, 2010). Esse princípio expressa a alteração da clássica relação das mídias referente às ações do emissor e receptor e viabiliza que esses dois papéis se entrelacem 
da mesma forma que os conceitos de educação, informação, comunicação e entretenimento. Para Lemos e Lévy (2010, p. 25),

[...] qualquer pessoa, e não apenas as empresas de comunicação, tem o poder de consumir, produzir e distribuir informação sob qualquer formato em tempo real e para qualquer lugar do mundo sem ter de movimentar grandes volumes financeiros ou ter que pedir concessão a quem quer que seja.

A sociedade da informação é a noção proposta por D. Bell para destacar o novo contexto socioeconômico-tecnológico oriundo da década de 80, que tem como característica a não centralidade da produção fabril ou da mídia de massa. Essa sociedade da informação se fundamenta na informação digital "como nova infraestrutura básica, como novo modo de produção” (KUMAR, 1997, p. 24). Para Castells (1999, p. 47), trata-se de uma sociedade na qual os modos de geração de conhecimento e processamento de informação foram alterados pela "revolução tecnológica centrada no processamento de informação, na geração do conhecimento e nas tecnologias da informação".

O crescente cenário da cibercultura e da sociedade da informação fomentam situações socioculturais que propõem diariamente ao campo educacional o desafio de ensinar e aprender com as mídias. Esse desafio começa a aparecer para os educadores com a emergência da Web na metade dos anos 90 (SANTOS, 2008), de modo que as mídias são, hoje, uma realidade irrefutável, uma vez que o cotidiano está cada vez mais caracterizado por ações que deixam evidentes essa realidade. Em face dessa realidade, este artigo versa sobre a integração das mídias nos processos educacionais, ressaltando a apropriação qualitativa das mídias que ultrapassa o seu uso instrumental em sala de aula.

\section{Noções sobre Apropriação Instrumental e Leitura Crítica das Mídias}

Se, por um lado, as mídias contribuem para uma mudança sociocultural, para potencializar a comunicação, compartilhar informações e expandir serviços, por outro, fazem crescer inquietações no campo da educação sobre a necessidade de transformar essa informação em conhecimento e, este, em resultados de aprendizagem (AMARAL; BOHADANA, 2008). Ou seja, faz-se necessária a consolidação de um lugar na educação para 
as mídias, onde, nesse processo, a educação se coloca como a estrutura capaz de sustentar a transformação das mídias e do que é veiculado nelas em conhecimento, e este, em resultados de aprendizagem, diminuindo assim, a inquietação.

Nesse sentido, sem perder a sua característica própria de promover a educação formal, as instituições de ensino necessitam construir e consolidar propostas pedagógicas que dialoguem com as mídias. Essa presença das mídias na educação, mais precisamente em sala de aula, não deve ser entendida somente como um recurso para dinamizar as aulas e entreter os estudantes. A inclusão das mídias no processo educativo pressupõe uma mudança para muitos docentes, uma vez que o verdadeiro professor será aquele que souber orientar o seu discente na procura e no acesso à informação necessária de modo que possa encaminhá-lo à construção do conhecimento (LEITE, 2008).

Sabemos que a esfera educacional tem suas atividades cada vez mais influenciadas pela intensa presença das mídias, ainda que, muitas vezes, nas escolas e universidades seus usos nos processos educacionais sejam limitados, por exemplo, à fonte de pesquisa. Dado o caráter informativo de algumas mídias, na educação elas funcionam constantemente como um "grande banco de dados", no qual o estudante vai em busca de determinada informação para em seguida inseri-la em seu trabalho, frequentemente sem verificar a sua veracidade. Utilizar as mídias na educação apenas como fonte de informações, ou meio de pesquisa, desvaloriza as suas potencialidades e as insere nos moldes da "educação bancária” ${ }^{1}$ (FREIRE, 1987, p.84), na qual a educação se faz da mídia para estudante ou da mídia sobre o estudante.

Essa capacidade informativa das mídias não deve ser desconsiderada, mas sim, trabalhada com bastante detalhe pelos profissionais da educação. Ademais, a integração das mídias nas práticas pedagógicas precisa considerar o aspecto transmissor e de informação da mídia de massa e o caráter colaborativo, interativo e de autoria da mídia digital. Com as mídias, o professor tem a oportunidade de coordenar a exposição dos resultados da pesquisa, questionar, contextualizar e adaptar à realidade dos estudantes. Emerge, assim, a necessidade de um docente que interaja efetivamente com o estudante "enquanto ser humano que tem sensibilidade para perceber e atender às suas necessidades e aos interesses pessoais - tarefa que o computador não pode desempenhar bem” (LEITE, 2008, p. 65, 72). Silva (2010a, p. 
88) propõe ao docente a interrupção, e não a exclusão, do falar/ditar, para que sejam disponibilizadas ao aluno a "autoria, participação, bidirecionalidade e informações o mais variadas possível, facilitando permutas, associações, formulações e modificações de conteúdos, de dados”.

À medida que as instituições de ensino passam a apoiar a integração das novas mídias em suas salas de aula e a investir na formação de seus professores para o uso das mesmas, articulando-as à docência e à aprendizagem, torna-se possível um aproveitamento mais eficaz, que possibilita transformar informação em conhecimento. Para introduzir efetivamente as mídias na educação, as escolas e universidades precisam dar-se conta de que somos influenciados por elas e, por isso, tornar-se indispensável incluí-las na formação do professor e discutir o seu papel no contexto social. Assim entendido, a educação e o professor necessitam de uma "nova pedagogia” que desmistifique as mídias na dimensão de “objeto de estudo” e como “ferramenta pedagógica” (BELLONI, 2009, p. xiv).

Afirmamos que, com a farta disponibilidade das mídias, emerge a urgência de formar profissionais da educação capazes de se apropriarem delas em sua prática. Nesse contexto, o uso das mídias para além do uso instrumental é um dos assuntos que norteia os debates sobre as mesmas na esfera educacional. A “lógica instrumental” é o agir estratégico, essencialmente técnico, voltado para o sucesso e os fins de controle e dominação. A ação instrumental rege-se por regras técnicas baseadas no saber prático e "organiza os meios adequados ou inadequados segundo os critérios de um domínio eficaz da realidade” (HABERMAS, 1980, p. 320).

No Brasil, essa lógica instrumental pode ser identificada na tendência pedagógica denominada "tecnopedagogia”, que foi implantada durante o governo militar como alternativa à educação popular de cunho político. A racionalização do sistema de ensino buscava garantir um resultado que atendia às necessidades da ideologia empresarial, que era o modelo econômico vigente. Fundamentada nas tendências do comportamentalismo e positivismo lógico, essa ideologia se concretizava na política administrativa do Estado autoritário e na educação (D’ÁVILA, 2008).

O ensino tecnicista é a essência da tecnopedagogia, definindo os próprios objetivos de ensino-aprendizagem e as finalidades da educação escolar. Sendo assim, essa 


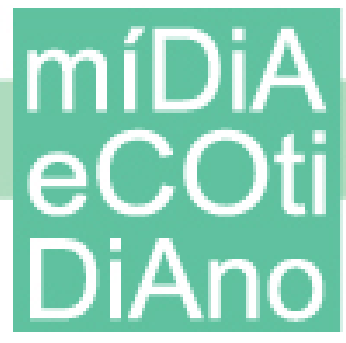

tendência visava reduzir os objetivos do ensino à instrução (D’ÁVILA, 2008). Outro aspecto norteador da tecnopedagogia é a teoria behaviorista de Skinner. O conceito principal da teoria é o comportamento operante, que é determinado pelo envolvimento estabelecido com o meio ambiente, ao receber desse, influências determinantes. Com essa teoria, as relações interpessoais são minimizadas e o individualismo fortalecido sobre as bases dos recursos tecnológicos que se colocam como primordiais. Ou seja, pensa-se que os alunos se relacionam com o meio técnico, presumindo que o modo de construção do conhecimento se dá através da relação recurso tecnológico sobre o aluno. Dessa forma, na tecnopedagogia tem-se o currículo sequencial, o ensino padronizado e a negligência aos talentos. Nessa tendência, a mediação didática docente ocorre em nome da técnica, passando, assim, a tecnologia a ser principal mediadora da aprendizagem e o professor seu administrador. Desse modo, a mediação é “estabelecida pelos próprios recursos tecnológicos inerentes a essa pedagogia” (D’ÁVILA, 2008, p. 64).

Com base na realidade da tecnopedagogia, Belloni (1998; 2009), Fantin (2010) e Soares (2007) alertam que é comum encontrar professores que trocam o quadro negro, a pesquisa em livros e a autoria docente pela exibição de um documentário na televisão, pela pesquisa na Web ou pela apresentação de slides. Essas ações podem se reduzir à instrumentalização, quando não há um direcionamento e articulação com a "leitura crítica das mídias” (BELLONI, 2009 p. 09). Na educação com, para, e através das mídias, isto é, na educação para as mídias ou mídia-educação, é necessário ultrapassar as "práticas meramente instrumentais, típicas de um certo tecnicismo redutor ou de um deslumbramento acrítico” (BELLONI, 2009, p. 13).

Os estudos de Belloni (2009, p. 13) sinalizam a necessidade de um salto qualitativo no trabalho docente e na formação de profissionais da educação que supere o “caráter simplificador das mídias na educação” para chegar à “mídia-educação”. A autora analisa a presença das mídias na esfera educacional em três dimensões: a que favorece a “inclusão digital”; como “objeto de estudo”; e como “ferramenta pedagógica”. Deste modo, Belloni (2009, p. xiv) conceitua como “mídia-educação” o conjunto dessas três dimensões, ressaltando que essa é uma "nova pedagogia” e um novo campo de conhecimento e práticas pedagógicas que reúnem diferentes trabalhos teóricos e práticos sobre os conteúdos das 
mídias e suas influências. Para a autora, a dimensão da “inclusão digital” se refere à apropriação dos modos de operar as máquinas que abrem caminho para a rede mundial de computadores, possibilitando que todos sejam autores e coautores de mensagens midiáticas. As mídias como “objeto de estudo” direcionam a "leitura crítica” das mensagens, que engloba a investigação dos procedimentos e mensagens midiáticas. Finalmente, a noção das mídias como "ferramentas pedagógicas” significa a dimensão do seu uso prático em situações de aprendizagem nos processos educacionais.

Igualmente, notamos que Belloni (2009, p. 9) distingue claramente as "práticas meramente instrumentais” da leitura crítica das mídias, propondo que a inclusão das mídias na educação não seja apenas segundo uma perspectiva instrumental, mas, também, no aspecto de leitura crítica. Por sua vez, Moran (1993), mesmo não fazendo essa distinção, oferece um argumento condizente com o da autora supracitada, ressaltando que estudar as mídias também de modo crítico torna-se o caminho para a superação da subutilização instrumental. Este autor usa a expressão "leitura crítica dos meios de comunicação" para sugerir uma forma de ler a mídia que tem caráter específico de dimensão política e pedagógica, e que está inserido em um processo de compreensão da realidade. A leitura dos meios possibilita que a estrutura empresarial e tecnológica da comunicação seja desvendada, bem como “o campo privilegiado da ideologia, pela força da persuasão e a abrangência dos meios de comunicação” (MORAN, 1993, p. 37). Somente com a leitura crítica dos meios é possível perceber a realidade da palavra proferida, mesmo na situação predominante de "receptor”. No dizer de Moran (1993, p. 52),

ler uma mensagem consiste em identificá-la dentro de nosso universo de compreensão, de valoração, de atuação. Cada mensagem situa-se dentro do espaço do nosso esquema mental, do nosso lugar cultural a partir do qual entendemos, valoramos, assumimos a realidade.

O autor ressalta, ainda, que a leitura crítica dos meios não pode ser interrompida no nível da representação. Ele destaca que é preciso considerar a dimensão material e a dimensão pragmática para fazer a leitura crítica. A dimensão material se concentra na comunicação como organização tecnológica, e a dimensão pragmática envolve o modo como os indivíduos se relacionam com as mensagens propostas. Moran discorre 


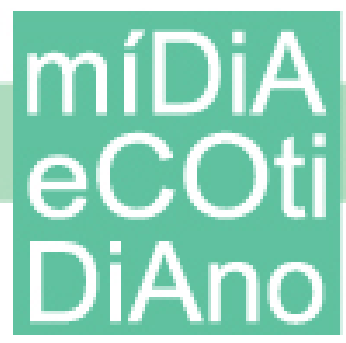

PPGMC

também sobre a educação para os meios, afirmando que outro problema sério na sua realização está em considerá-la como um momento meramente teórico. Educar para os meios “é um momento fundamentalmente prático, de intervenção no social, de síntese mobilizadora e de permanente reorganização e iluminação da realidade” (MORAN, 1993, p. 12).

Os estudos relativos às mídias, além de estarem presentes na área da educação, inserem-se em grande escala nas mais diversas críticas sociais contemporâneas. Muitos autores incluindo Silverstone (2002), Santos, M. (2008) Braga (2006) e Melo (2004) escrevem sobre o desafio de um olhar crítico sobre elas. Santos, M. (2008, p. 39), por exemplo, justifica a necessidade social de estudo das mídias afirmando que atualmente há um novo encantamento do mundo, em que o discurso e a retórica são o princípio e o fim. Para o autor, “esse imperativo e essa onipresença da informação são insidiosos, já que a informação atual tem dois rostos, um pelo qual ela busca instruir, e outro, pelo qual ela busca convencer”. Por sua vez, Braga (2006) adverte que é preciso desenvolver a crítica midiática em sua forma ampla e, com isso, entender que ela não está limitada às análises feitas por teóricos e intelectuais. Com essa afirmativa, ele enfatiza que existe uma crítica das mídias especializada e outra possível crítica das mídias feita pela sociedade. Portanto, compreendemos que essa crítica especializada não precisa ser exclusiva dos profissionais da comunicação, mas também pode ser elaborada pelos profissionais da educação.

São nesses sentidos do uso instrumental e da leitura crítica que se fundamenta as nossas reflexões. Diante dos citados pressupostos, faz-se premente a necessidade de docentes para o uso das mídias como ferramentas pedagógicas, mas, sem desconsiderar a fundamentação para a leitura crítica das mídias, pois, como ressalta Silverstone (2002), é por ser fundamental para nossa vida cotidiana que devemos estudar as mídias em sua dimensão social, cultural, política e econômica no mundo moderno. "Estudar a onipresença e sua complexidade. Estudá-la como algo que contribui para nossa variável capacidade de compreender o mundo, de produzir e partilhar significados” (SILVERSTONE, 2002, p. 13).

\section{Educando para as Mídias}


A educação para as mídias se justifica através de muitos argumentos. Masterman (1993 apud BELLONI, 2009, p. 09) pontua sete razões principais que são consistentes as mudanças no campo das mídias que são discutidas por Dizard, (2000, p. 13). Entre as razões, têm-se: alto consumo midiático; relevância ideológica das mídias, principalmente através da publicidade; gestão de informação nas empresas; participação crescente das mídias nos processos democráticos; crescimento da comunicação visual e da informação em todos os campos; expectativa dos jovens a serem formados para compreender sua época; crescimento nacional e internacional das privatizações de todas as tecnologias da informação.

Em consonância com o pensamento de Masterman (1993 apud BELLONI, 2009, p. 09), Silverstone (2002, p. 12) enfatiza que o estudo das mídias se justifica por questões que não podem ser desconsideradas. Entre essas questões, fala-se do reconhecimento de que a mídia é onipresente, diária, e, assim, torna-se uma dimensão essencial da nossa experiência contemporânea, de modo que, é difícil fugir à presença e à representação da mídia.

Essas funções que as mídias têm exercido na sociedade e na formação dos sujeitos precisam ser discutidas no contexto educacional (FANTIN, 2006). Compreendemos que todos os assuntos sociais, e, dentre estes, inserem-se as mídias, são centrais à educação, visto que tudo pode ser incluído na proposta de ensino-aprendizagem. Entretanto, a articulação entre educação e comunicação, ou seja, educação para mídias, ainda está longe de ser suficientemente estudada e praticada na esfera educacional.

A educação é concebida a partir de diversas perspectivas. Adotamos a abordagem de Freire (1987), que a compreende como o processo de construção da consciência crítica. Ele entende a educação como problematizadora, interativa, dialógica e transformadora, o que a distancia da neutralidade e de uma concepção simplificadora. O autor aposta na educação pela comunicação afirmando que “sem esta não há verdadeira educação” (FREIRE, 1987, p. 87). De fato, a forma como Lemos, Lévy (2010) e Silva (2010b) descrevem as potencialidades da cibercultura vai ao encontro da concepção de educação de Freire (1987). Todos esses autores, ainda que calçados em argumentos diferentes, defendem que não há processo de construção do conhecimento sem trocas, enunciação e indagação, em suma, sem comunicação.

Em sua definição mais simples no dicionário, entende-se comunicação como informação, transmissão, passagem, relação, interação, etc. Vários autores, ao definirem 


\section{míDiA

comunicação, aproximam-se da concepção de educação proposta por Freire (1987), destacando que a comunicação contribui para o processo de dinamização das interações sociais (BELTRÃO, 1983; MORAN, 1993; SANTOS, J., 1992). Por outro lado, a comunicação também é conceituada como a prática ou campo de estudo que se debruça sobre a "produção, a veiculação e a recepção das mensagens, tanto ao nível pessoal como social, tanto na esfera do privado como na esfera pública, e a interação dos emissores-receptores” (MORAN, 1993, p. 15).

As concepções de educação e comunicação citadas sugerem uma relação intrínseca e indissociável entre as áreas, correspondente ao que é apontado por Fantin (2006, p. 28): “Considerando que a comunicação é imprescindível para a educação, pois toda a prática educativa é uma prática comunicativa, a comunicação faz parte da educação e, neste sentido, não existe educação sem comunicação”.

Juntas, essas áreas podem fomentar novas formas de criar, pensar, interagir, aprender e ensinar, do mesmo modo que viabilizam o diálogo e as interações sociais. Diante disso, ressaltamos que a integração dos campos, isto é, o estudo específico das mídias na educação é um fenômeno que se fortaleceu com os meios de comunicação de massa e vem ganhando mais significado com as mídias digitais.

Em seus primórdios, na Europa, a mídia-educação se desenvolveu simultaneamente à formação da indústria cultural. No início do século $\mathrm{XX}$, as mídias eram vistas como anticulturais e, por isso, eram um mal que a educação deveria combater. Esse modo de compreender as mídias fomentou quatro concepções que marcam até hoje os estudos e práticas das mídias na educação. Essas concepções são: concepção inoculatória; concepção de leitura crítica; concepção das ciências sociais e; concepção ideológica (FANTIN, 2006).

A concepção inoculatória da educação para as mídias ressalta a força das mídias e a vulnerabilidade da audiência. Nesta concepção, a mídia-educação é vista como o instrumento para proteger os usuários dos perigos das mídias, configurando-se, assim, em sua fase inicial, como uma educação contra os meios. A segunda, a concepção de leitura crítica, ganha força na década de 60. Com o progresso do cinema, os textos das mídias passam a interessar os estudiosos e, assim, a educação para as mídias é marcada pela capacidade crítica e semiótica. A terceira, a concepção das ciências sociais, inclui a integração didática da mídia- 
educação entre os estudos da semiótica e da análise do consumo. Na quarta concepção, a ideológica, as mídias são vistas como instrumento de luta, fazendo com que a educação para as mídias fique às margens da educação formal, com vinculação mais significativa à militância do que a área acadêmica (FANTIN, 2006).

No Brasil, entre os anos 70 e 80, por exemplo, experiências de análises das mídias na escola já estavam sendo desenvolvidas. Esses estudos buscavam entender as mídias através de uma visão menos ingênua e mais crítica, conhecendo e estudando melhor a linguagem e produzindo novos produtos de mídias (MORAN, 1993). Neste período, defendia-se o desenvolvimento de uma educação que incluísse as mídias na formação de professores. No entanto, dentro dessa educação, não era satisfatório “colecionar [...] audiovisuais informatizados ou saber sobre suas técnicas, era necessário aprender a elaborar e a intervir no processo comunicacional que se dá entre professores e alunos com essas mídias” (FUSARI, 1995 apud FANTIN, 2006, p. 28).

A noção de educação para as mídias começou a ser incluída na pauta de discussões da Organização das Nações Unidas para a Educação, a Ciência e a Cultura (UNESCO) na década 70. Inicialmente, em 1973, a UNESCO apresentava a escola como único espaço para o desenvolvimento dessa educação. Na década seguinte, no documento Éducation aux médias (UNESCO, 1984), a Organização redefine a concepção da educação para as mídias, enfatizando que ela não está restrita aos espaços escolares, pois “abrange todas as maneiras de estudar, de aprender e de ensinar em todos os níveis [...] e em todas as circunstâncias, a história, a criação, a utilização e a avaliação das mídias”. Somada à alfabetização literária, a educação, sob esta ótica, deve promover essa alfabetização para os meios.

Para Rivoltella (2002 apud FANTIN, 2006, p.51) essa nova concepção da UNESCO (1984) harmoniza a mídia-educação enquanto prática social e disciplina curricular. Esses dois campos de atuação giram em torno da formação de crianças, jovens e adultos através do trabalho com os “conteúdos” e linguagens da alfabetização midiática. Assim, pretendem-se capacitar os sujeitos para ler e escrever criticamente com as mídias, ao mesmo tempo em que se discutem temas do campo da educação para as mídias, entre eles, a igualdade, os direitos de acesso, a participação e a cidadania. 
No contexto brasileiro, especificamente nos anos 90, há avanços nos estudos entre educação e comunicação, apesar das contradições teóricas e metodológicas. Neste período, a análise das mídias era direcionada para a concepção crítica, supervalorizando a ideologia. Com esse procedimento, os pesquisadores desconsideram a dimensão do lazer, da fantasia e da emoção que fazem parte da interação das mídias com a sociedade, dedicando-se apenas a analisar as mídias e sua relevância ideológica (MORAN, 1993).

Conforme exposto, são muitas as concepções e nomenclaturas que convergem da interface educação e comunicação. Dentre elas, destaca-se a “educomunicação” (SOARES, 2002), que representa uma inter-relação entre essas duas áreas. Segundo Soares, a educomunicação permite aos educadores e estudantes uma nova participação nos processos comunicativos propiciados por um grupo de ações intrínsecas ao "planejamento, implementação e avaliação de processos, programas e produtos destinados a criar e fortalecer ecossistemas comunicativos em espaços educativos” (SOARES, 2002, p. 115).

Fantin (2006) define a mídia-educação listando três fios que a tecem. O primeiro, o da cultura, contempla a possibilidade de ampliação de diversos repertórios culturais. O segundo fio é o da crítica, que abrange a capacidade de análise, reflexão e avaliação. O terceiro, o fio da criação, compreende a capacidade criativa de expressão, de comunicação e de construção de conhecimentos. A essas três palavras, “cultura”, “crítica” e “criação”, que começam com a letra C, a autora acrescenta a “cidadania”, enfatizando que a mídia-educação é uma condição para a cidadania. Observamos que a concepção de educação para as mídias de Fantin (2006) é consistente com aquela proposta desenvolvida pela UNESCO em 1984.

Essa visão é corroborada também por Belloni (2009), que enfatiza a mídiaeducação como indispensável para o progresso das práticas educativas democratizantes e essencial para o exercício da cidadania. Essas práticas incluem uma formação de professores atualizada e em sintonia com as maneiras de ser e de aprender das novas gerações.

Apesar das variações terminológicas, tanto a educomunicação quanto a mídiaeducação objetivam uma formação dentro da área educacional voltada a um usuário participativo, crítico e criativo diante das mídias. Nesse sentido, explorar as mídias pedagogicamente implica reinventar a educação em todos os níveis e formas, fomentando uma transformação de magnitude tal que afeta profundamente os docentes e discentes. $\mathrm{O}$ 
professor precisa conhecer as potencialidades das mídias para que possa incluí-las em sala de aula de modo a ultrapassar o mero uso das mídias pelas mídias. Nesse sentido, “a educação para as mídias não se reduz aos meios e a seus aspectos instrumentais, pois as mídias situamse numa arena de produção de significados” (FANTIN, 2006, p. 31).

A noção de que as mídias estão em um campo de produção de significados condiz com o princípio de liberação do polo da emissão, já apresentado em termos da liberação da palavra proposta por Lemos e Lévy (2010). Em seu significado, esse princípio reflete um aspecto da cibercultura, onde os sons, imagens e textos são produzidos e distribuídos livremente, resultado da paisagem comunicacional contemporânea proporcionada pelas novas mídias e suas funções pós-massivas.

Nesse contexto, pensar em educação para as mídias envolve entender as lacunas nesta formação, ou seja, aquilo que se pode fazer e não se faz, e que contornos a utilização desses equipamentos midiáticos estão tomando em sala de aula. Envolve, também, pensar em como poderá a educação contribuir para que os estudantes que estão nas escolas e universidades se tornem usuários criativos e críticos destas mídias e "não meros consumidores compulsivos de representações novas de velhos clichês” (BELLONI, 2009, p. 08).

\section{Conclusão}

Um dos desafios para os pesquisadores da Educação e da Comunicação contemporâneas são as discussões acerca da apropriação das mídias na educação. Os diversos usos das mídias, podendo levar à construção do conhecimento, fomentam o surgimento de questões que vão desde a necessidade social de incluí-las até as diferentes formas de se apropriar delas na esfera educacional.

Sabemos que existem políticas educacionais de articulação entre as mídias e a educação ${ }^{2}$ que fomentam a crescente presença das mídias nas salas de aula e, segundo Gaddotti (2000, p. 73), a educação deve servir de bússola para navegar nesse mar do conhecimento e práticas instrumentais que vêm com as mídias, "superando a visão utilitarista de só oferecer informações ‘uteis’ à competitividade, para obter resultado”. Essa mudança de 
postura requer uma formação para o uso das mídias que possibilite harmonicamente a orientação para a apropriação instrumental acoplada à leitura crítica das mídias. Acreditamos que a apropriação das mídias enquanto ferramenta pedagógica e objeto de estudo possibilita o desenvolvimento de ações pedagógicas mais enunciativas, criativas e colaborativas, consistentes com o princípio da cibercultura.

Assim, esperamos que esta discussão se configure em uma discreta contribuição para a compreensão de que a inclusão das mídias na educação não pode limitar-se às ações práticas isoladas. De fato, as reflexões trazidas neste texto evidenciam a premência de uma educação para as mídias que contemple uma formação para a sua leitura crítica bem como suas diferentes apropriações. Que este artigo seja um convite para o desenvolvimento de pesquisas dedicadas a essa problemática, particularmente no que se refere à articulação entre a presença das mídias na educação em suas dimensões de ferramenta pedagógica e objeto de estudo.

\section{Referências}

AMARAL, Mirian Maia do; BOHADANA, Estrella. Conectividade e mobilidade social: pilares da inclusão digital?. Contemporânea, v. 6, n. 2, dez. 2008. p. 1-21.

BELLONI, Maria Luiza. O que é mídia-educação. 3.ed. rev. Campinas: Autores Associados, 2009.

Tecnologia e formação de professores: rumo a uma pedagogia pós-moderna?. Educação e Sociedade, Campinas, v. 19, n. 65, dez. 1998. p. 143-162.

BELTRÃO, Luiz. Processo da Comunicação. In: SILVA, Roberto de Queiroz e (Org.). Temas básicos em comunicação. São Paulo: Edições Paulinas, 1983, p. 13-16.

BRAGA, José Luiz. A sociedade enfrenta sua mídia: dispositivos sociais de crítica midiática. São Paulo: Paulus, 2006.

BRASIL. Conselho Nacional De Educação/Conselho Pleno. Parecer n. ${ }^{\circ}$ 1, de 15 de maio de 2006, sobre as Diretrizes curriculares nacionais para o curso de Pedagogia. Ministério da Educação, Brasília, DF, 15 de maio. 2006.

CASTELLS, Manuel. A sociedade em rede. São Paulo: Paz e Terra, 1999. 


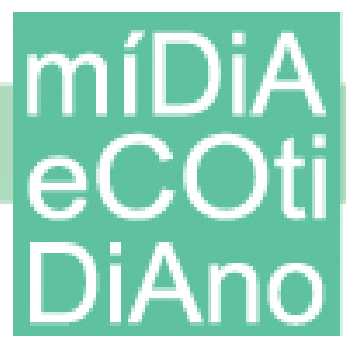

D’ÁVILA, Cristina Maria. Decifra-me ou te devorarei: o que pode o professor frente ao livro didático. Salvador: Eduneb; Edufba, 2008.

DIZARD, Wilson. A nova mídia: a comunicação de massa na era da informação. 2.ed. Rio de Janeiro: Jorge Zahar, 2000.

FANTIN, Mônica. Dos consumos culturais aos usos das mídias e tecnologias na prática docente. Motrivivência, Santa Catarina, n. 34, jun. 2010. p. 12-24.

.Mídia-Educação: conceitos, experiências, diálogos Brasil-Itália. Florianópolis: Cidade Futura, 2006.

FREIRE, Paulo. Pedagogia do oprimido. 17.ed. Rio de Janeiro: Paz e Terra, 1987.

GADOTTI, Moacir. Perspectivas atuais da educação. Porto Alegre: Artmed, 2000.

HABERMAS, Jürgen. Técnica e ciência enquanto ideologia. In: BENJAMIN, Walter; HORKHEIMER, Max; ADORNO, Theodor; HABERMAS, Jürgen. Textos escolhidos. Trad. Zeljiko Loparic e Andréa Maria Altino de Campo Loparic. São Paulo: Abril Cultural, 1980. p. 313 - 343. (Coleção Os pensadores).

KUMAR, Krishan. Da sociedade pós-industrial à pós-moderna. Rio de Janeiro: Zahar, 1997.

LEITE, Lígia Silva. Mídia e a perspectiva da tecnologia educacional no processo pedagógico contemporâneo. In: FREIRE, Wendel (Org.). Tecnologia e educação: as mídias na prática docente. Rio de Janeiro, Wak, 2008. p. 61-77.

LEMOS, André; LÉVY, Pierre. O futuro da internet: em direção a uma ciberdemocracia planetária. São Paulo: Paulus, 2010.

LÉVY, Pierre. Cibercultura. Rio de Janeiro: Ed. 34, 1999.

MELO. José Marques. Comunicação social: da leitura à leitura crítica. In: ZILBERMAN, Regina; SILVA, Ezequiel Theodoro da (Org.). Leitura: perspectivas interdisciplinares. 5 ed. São Paulo, Ática, 2004. p. 100-110.

MORAN, José Manuel. Desafios na comunicação pessoal: gerenciamento integrado da comunicação pessoal, social e tecnológica. 3.ed. São Paulo: Paulinas, 2007.

. Leitura Crítica dos Meios. São Paulo: Pancast, 1993.

SANTOS, Edméa Oliveira. A metodologia da webquest interativa na educação online. In: FREIRE, Wendel (Org.). Tecnologia e educação: as mídias na prática docente. Rio de Janeiro, Wak, 2008. p. 107-128. 
SANTOS, José Rodrigues dos. O que é Comunicação. Lisboa: Difusão Cultural, 1992, p. 911.

SANTOS, Milton. Uma globalização perversa. In.: Por uma outra globalização: do pensamento único à consciência universal. 15. ed. Rio de Janeiro: Record, 2008. p. 37-71.

SILVA, Marco. Sala de Aula Interativa. 5. ed. São Paulo: Edições Loyola, 2010a.

Inclusão Digital: algo mais do que ter acesso às tecnologias digitais. In: RANGEL, Mary; FREIRE, Wendel (Org.). Ensino-aprendizagem e comunicação. Rio de Janeiro, Wak, 2010b. p. 131-147.

SILVERSTONE, Roger. Por que estudar a mídia?. São Paulo: Loyola, 2002.

SOARES, Ismar. A mediação tecnológica nos espaços educativos: uma perspectiva educomunicativa. Comunicação e Educação, São Paulo, ano 12, n. 1, jan/abr, 2007. p. 31-40.

Metodologias da educação para a comunicação e gestão comunicativa no Brasil e na America Latina. In: BACCEGA, Maria Aparecida (Org.). Gestão de processos comunicacionais. São Paulo: Atlas, 2002.

TAPSCOTT, Don; WILLIANS, Anthony D. Wikinomics: a nova economia das multidões inteligentes. Lisboa: Quidnovi, 2008.

UNESCO, 1984. Éducation aux médias. Paris, Unesco.

\footnotetext{
${ }^{1}$ A “educação bancária” era intensamente criticada por Freire (1987, p. 84) que enfatizava que a educação autêntica não se faz de A para B ou de A sobre B e sim, de A com B.

${ }^{2}$ Um exemplo dessas políticas está na Resolução nº 1/2006, do Conselho Nacional de Educação/ Conselho Pleno (BRASIL, 2006), que determinou que o curso de Pedagogia deve "relacionar as linguagens dos meios de comunicação à educação, nos processos didático-pedagógicos, demonstrando domínio das tecnologias de informação e comunicação adequadas ao desenvolvimento de “aprendizagens significativas””.
} 